\title{
Article \\ Persistent Organic Pollutants and Metals in Atmospheric Deposition Rates around the Port-Industrial Area of Civitavecchia, Italy
}

\author{
Gaetano Settimo ${ }^{1, *(\mathbb{D}}$, Maria Eleonora Soggiu ${ }^{1}\left(\mathbb{D}\right.$, Marco Inglessis $^{1}\left(\mathbb{D}\right.$, Giovanni Marsili $^{2}$ and Pasquale Avino ${ }^{3, *(\mathbb{D})}$ \\ 1 Italian National Institute of Health, Viale Regina Elena 299, I-00185 Rome, Italy; \\ mariaeleonora.soggiu@iss.it (M.E.S.); marco.inglessis@iss.it (M.I.) \\ 2 Consorzio per la Gestione dell'Osservatorio Ambientale, Via delle Saline 18, Tarquinia, I-01100 Viterbo, Italy; \\ marsiligianni@gmail.com \\ 3 Department of Agriculture, Environmental and Food Sciences, University of Molise, Via F. De Sanctis, \\ I-86100 Campobasso, Italy \\ * Correspondence: gaetano.settimo@iss.it (G.S.); avino@unimol.it (P.A.); Tel.: +39-06-49902845 (G.S.); \\ +39-06-0874-404631 (P.A.)
}

check for

updates

Citation: Settimo, G.; Soggiu, M.E.; Inglessis, M.; Marsili, G.; Avino, P. Persistent Organic Pollutants and Metals in Atmospheric Deposition Rates around the Port-Industrial Area of Civitavecchia, Italy. Appl. Sci. 2021, 11, 1827. https://doi.org/10.3390/ app11041827

Academic Editors: Pierina Ielpo, Paola Fermo and Constantini Samara

Received: 15 January 2021

Accepted: 9 February 2021

Published: 18 February 2021

Publisher's Note: MDPI stays neutral with regard to jurisdictional claims in published maps and institutional affiliations.

Copyright: (c) 2021 by the authors. Licensee MDPI, Basel, Switzerland. This article is an open access article distributed under the terms and conditions of the Creative Commons Attribution (CC BY) license (https:/ / creativecommons.org/licenses/by/ $4.0 /)$.
Featured Application: The deposition rate is a relevant and novel issue in air quality evaluation. Particularly, atmospheric micropollutant deposition rate measures represent a strategic element in environmental surveillance and in population exposure evaluation for POPs and metals.

\begin{abstract}
In recent years, studies on climate change have focused on reducing greenhouse gas emissions emitted by various civil and industrial processes. This study highlights the importance of characterizing the total deposition rates of airborne particles (bulk atmospheric deposition) in the surroundings of an industrial area along the north cost of the Lazio Region in Italy, to deepen knowledge about the potential impact of emissions from the coal-fired thermoelectric (CTE) power plant and other possible sources existing in the surrounding area. Four sampling sites were identified, and the monitoring plan was performed a yearlong with monthly collecting observation. The deposition samples were collected monthly and processed for determining organic (polychlorinated dibenzo-para-dioxins, PCDDs; polychlorinated dibenzofurans, PCDFs; dioxin-like polychlorinated biphenyls, DL-PCBs; polycyclic aromatic hydrocarbons, PAHs) and inorganic (metals) substances. The samples were collected monthly and sent for chemical characterization. In Europe and Italy, no reference values have been given for the deposition rates of chemicals, while some European countries have determined reference/guide values to which the authors will refer in this study. Therefore, the analytical results show that the deposition rates for PCDD/Fs and DL-PCBs are lower with respects guide values defined by Germany and Belgium; PAHs values are in line with those measured in other rural-type sites, while for metals the analytical results show a situation between rural and urban area. The approach used in this study can help to identify reference values for Italy in deposition rates, with the aim both to characterize the dynamic of pollution in area with multiple risk factors and to describe and protect human health from environmental exposures caused by the contamination of the food chain.
\end{abstract}

Keywords: deposition rate; sedimentable dust; air quality; climate change; POPs; PCDD/Fs; DLPCBs; PAHs; metals; industrial area; fossil fuel; emissions; greenhouse effect; chemometric

\section{Introduction}

Atmospheric pollutant emissions due to anthropogenic activities cause the deposition of airborne particles, with negative effects on human health, environment, food and ecosystem [1-3]. National legislation and European directives define the term total or bulk deposition as "the total mass of pollutants which is transferred from the atmosphere 
to surfaces (e.g., soil, vegetation, water, buildings, etc.) in a given area within a given time" $[4,5]$. The deposition rate is expressed as surface mass for a given reference period, generally in $\mu \mathrm{g}$ of pollutant per $\mathrm{m}^{2}$ per day $\left(\mu \mathrm{g} \mathrm{m}^{-2} \mathrm{~d}^{-1}\right)$. At present, in Italy there are no regulations, guidelines and limits for airborne pollutant depositions. However, we can refer both to measures in similar areas, to the scientific literature and to guidelines and/or rules in force in other countries. For example, about polychlorinated dibenzo-para-dioxins and polychlorinated dibenzofurans (PCDD/Fs) and dioxin-like polychlorinated biphenyls (DL-PCBs), Belgium suggests a maximum value of 8 pg World Health Organization-Toxic Equivalent concentrations (WHO-TE) $\mathrm{m}^{-2} \mathrm{~d}^{-1}$ based on the human tolerable weekly intake (TWI) [6]; while Germany, using a guideline approach, for PCDD/Fs and DL-PCBs only, suggests 4 pg WHO-TE $\mathrm{m}^{-2} \mathrm{~d}^{-1}$ [7].

Different studies were performed for investigating organic [8-16] and inorganic micropollutants [17-32] in atmospheric deposition using bulk deposition methods. The total depositions (bulk) are collected by passive exposure of a "bottle/cylindrical funnel" system with standardized dimensions, for weekly and/or monthly collecting period in annual monitoring studies. Deposition rates of some atmospheric pollutants measured by means of bulk deposimeter (passive exposure of a "bottle/cylindrical funnel" system of standardized dimensions) is an important tool to evaluate environmental pollution levels and to assess population exposure [33,34]. Deposition samples are particularly suitable to measure the environmental concentration of Persistent Organic Pollutants (POPs), as PCDD/F, PCB and polycyclic aromatic hydrocarbons (PAHs) [34-38]. For these reasons, the pollutant downfall from atmosphere to soil both in environmental surveys and in monitoring networks, are very important for the information on the area's contamination allowing to perform a comprehensive assessment of the population exposure.

Emissions from different sources (e.g., petrochemicals, refinery, metal industry, large combustion plants, landfill, waste incineration, and cement factories) [39-45] cause contamination of farmlands and a potential subsequent accumulation in the food chain (in which POPs are particularly associated with fats) [46-49]. Italy has drawn up the National Energy Strategy (NES) and the Integrated National Plan for Energy and Climate (INPEC) which contain the national targets for 2030 which provide for the decarbonization of the energy system starting from 2025, with a sharp cut in use of coal for the production of electricity. In this frame, electricity production is a major source of greenhouse gas emissions. Strategies to reduce greenhouse gas emissions from electricity generation include switching to renewable energy sources.

The study, addressed to characterize the related organic and inorganic dust fractions, aims to carry out a characterization of the sedimentable particulate material in the area of Civitavecchia (North Latium, Central Italy) and the neighboring municipalities in order to understand the potential impact on the territory of the emissions of a coal-fired thermoelectric (CTE) power plant and of the other pressure sources existing in the area.

\section{Materials and Methods}

The locations of the deposimeters (Figure 1) have been identified, taking into account the characteristics of the territory, distributing them on the various municipalities around Civitavecchia (North Latium, Central Italy). The location of Rocca Respampani, in the territory of Viterbo, very far from any known industrial/urban emission source, has been identified as a background location. The monitoring network installed for the study consisted of:

- Location \#1: area not affected by industrial and urban sources; positioning: at the Roccaccia Business Center, Tarquinia Agricultural University;

- Location \#2: area characterized by the absence of settlements; positioning: Enel Sant'Agostino electrical power station;

- Location \#3: area characterized by medium population density; positioning: at the environmental monitoring station of the Management Consortium of the Environmental Observatory of Civitavecchia, at Allumiere; 
- Location \#4: area not affected by industrial and urban sources; positioning: at the

Rocca Respampani Agricultural Company (background site).

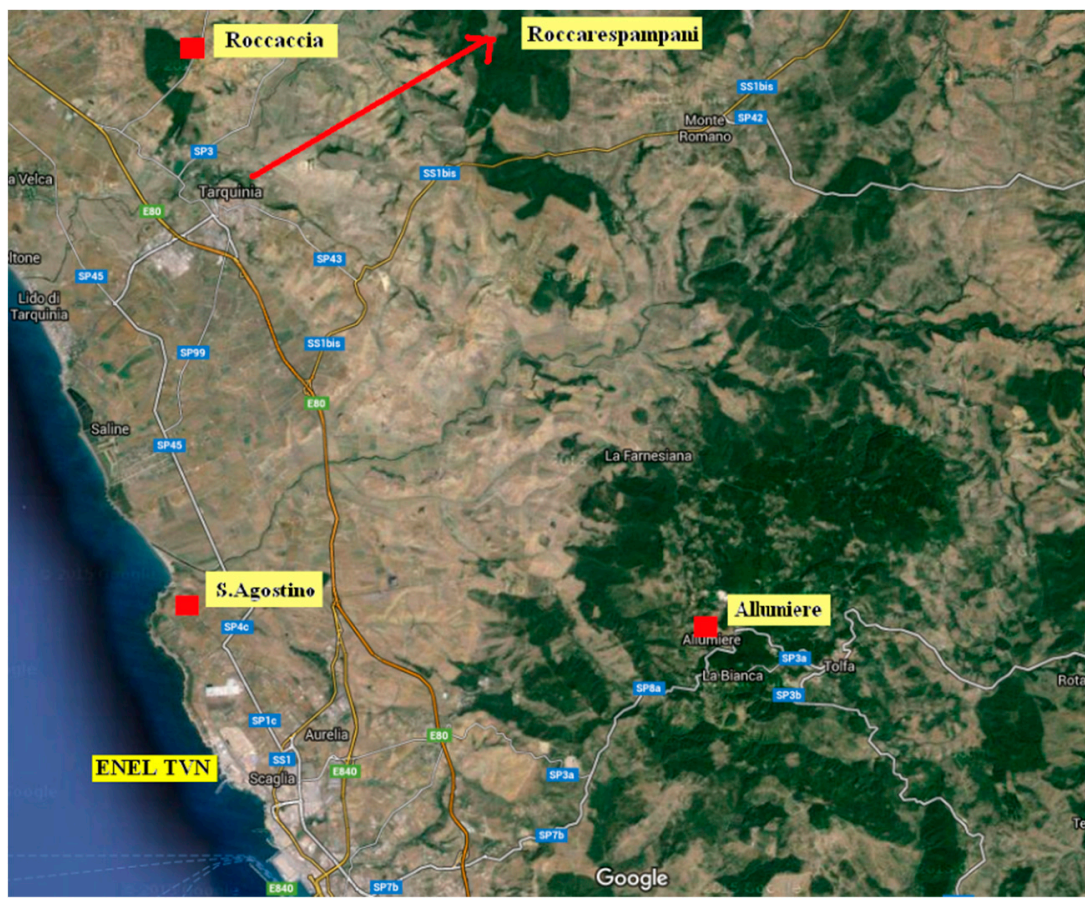

(a)

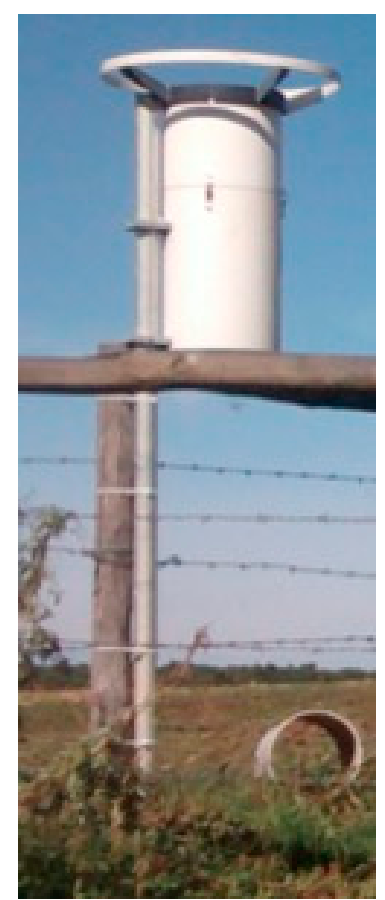

(b)

Figure 1. (a) Location of the four sampling sites around Civitavecchia and neighboring municipalities; (b) total bulk deposimeter sampler used in this campaign.

An ambient air monitoring network was installed consisting of four stations equipped with total bulk deposimeters (Figure $1 \mathrm{~b}$ ) for determining the atmospheric deposition rate. The determinations of organic (PCDD/Fs, DL-PCBs and PAHs) and inorganic (metals and metalloids) micro-pollutants at (ultra-)trace levels were carried out on all the samples collected. The sampling started at the four sites from June and continued for a whole year, each lasting about 30 days. Each sampling was performed following the indications reported in the Italian Legislative Decree no. 155/2010 [50]: UNI EN 15980:2011 for organic micropollutants [51] and UNI EN 15841:2010 for metals and metalloids [52]. Pyrex glass deposimeters were used for the determination of PCDD/Fs, PCBs and PAHs, while high-density polyethylene (HDPE) deposimeters were used for metals and metalloids.

The samples were filtered on a membrane filter in mixed cellulose esters, diameter $47 \mathrm{~mm}$ and porosity $0.45 \mu \mathrm{m}$ for metals, and in glass fiber, diameter $47 \mathrm{~mm}$, without organic binders, for organic compounds. The mixed cellulose ester filter was then mineralized in a microwave digestion system using concentrated nitric acid and $5 \%$ hydrogen peroxide, and the acidified filtrate with high purity concentrated nitric acid for trace analysis, whereas the glass fibers and the filtrate were subjected to extraction with high purity organic solvent for trace analysis (dichloromethane, DCM), respectively, by ultrasound and in a separating funnel. The acid solution coming from the mineralization and the acidified filtrate were analyzed by Inductively Coupled Plasma-Mass Spectrometry (ICP-MS), using the procedure described in UNI EN 15841:2009 [52], whereas the extracts with the solvent were combined, dried, concentrated and analyzed for determining PCDD/Fs by means of gas chromatography coupled with mass spectrometry (GC-MS) according to UNI EN 1948-2:2006 [53], UNI EN 1948-3:2006 [54] and UNI EN 1948-4:2010 [55], and for determining PAHs by means of high performance liquid chromatography-MS (HPLC-MS) according to UNI EN 15980:2011 [51]. In the analytical results, the concentration values below the limit of 
detection (LOD) are expressed as 50\% of the LOD, as indicated in [32]. The LODs for each compound/metal investigated are reported in Table S1 of the Supplementary Material.

\section{Results and Discussion}

The approach used in this study has been addressed to maximize all the information: first, the meteorological conditions had been studied, further the deposition rates have been investigated and interpreted in relationship to the related findings. As reported above, the authors would like to underline in Italy no regulations, guidelines and/or limits law limits or national guidelines for airborne pollutant depositions at present: therefore, the authors performed a comparison of observed with guidelines and/or values recommended by other European countries.

\subsection{Analysis of the Prevailing Wind Direction}

For the analysis of the meteorological conditions present during the monitoring campaign, the data acquired by the station positioned at a height of $120 \mathrm{~m}$, located inside the CTE central station were analyzed. The available data covers the entire sampling period (Figure 2).
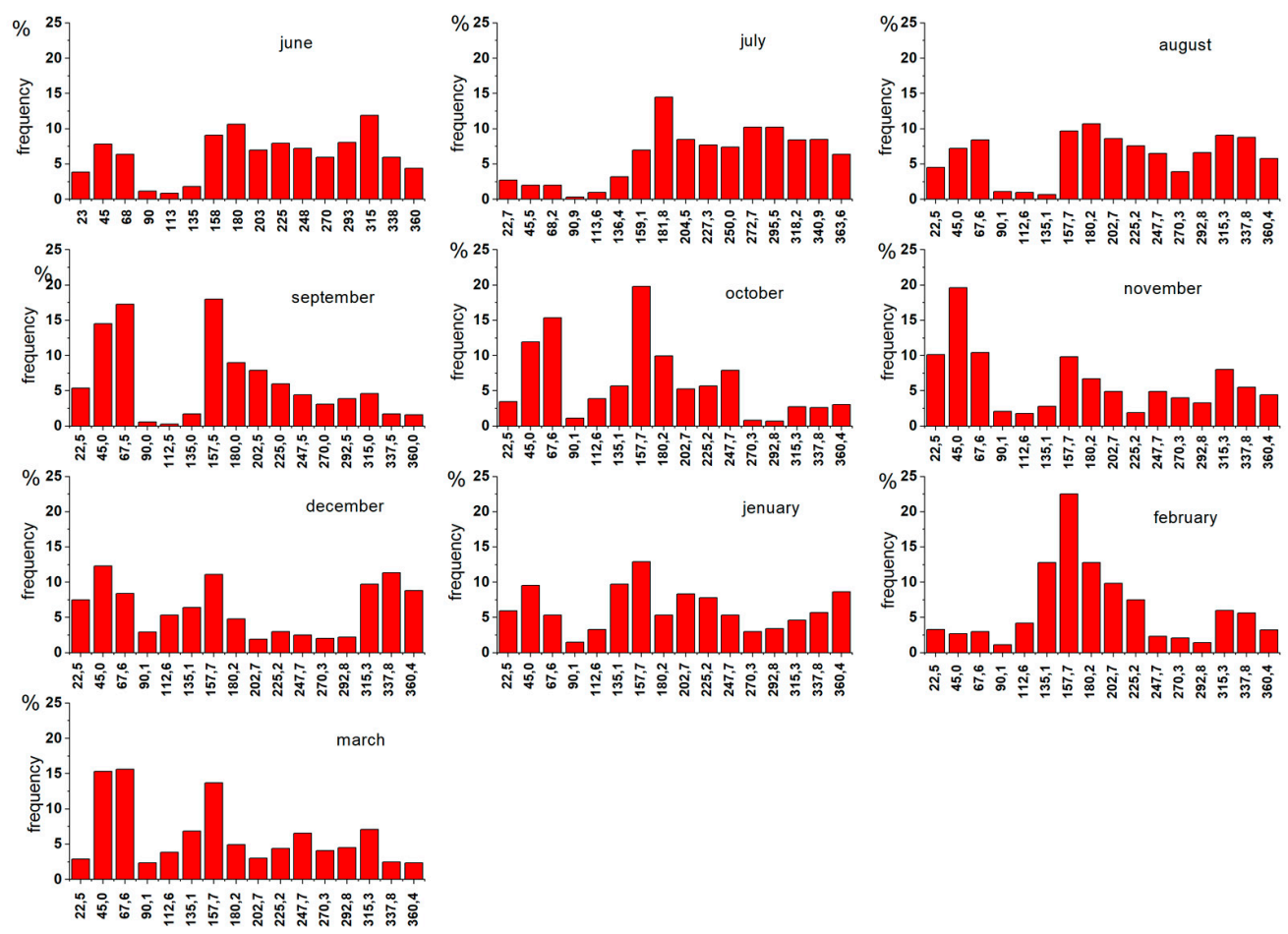

Figure 2. Frequency distribution of wind direction month by month.

During the study, the frequencies of the wind direction showed the expected seasonal variability. In general, the winds from the East have low frequencies, in some periods they seem to be absent. The most frequent directions are those associated with the whole sector that goes from South-West to North-West, the winds from the South are predominant in the months of October and February, whereas the North-East sector is present with higher frequencies in the months of September, October, November and March.

The wind directions change during the hours of the day: this occurs during the whole year. Until mid-morning the main frequency of wind directions are from North-East and from South-East; in the afternoon, the wind direction turns, and the West and North-West directions are predominant, with the North-North West sector prevalent during 16-19.

The wind speeds show a variability related to the sector of origin of the winds. On average, higher speeds are associated with winds from North-East and South-East (Figure 3). 


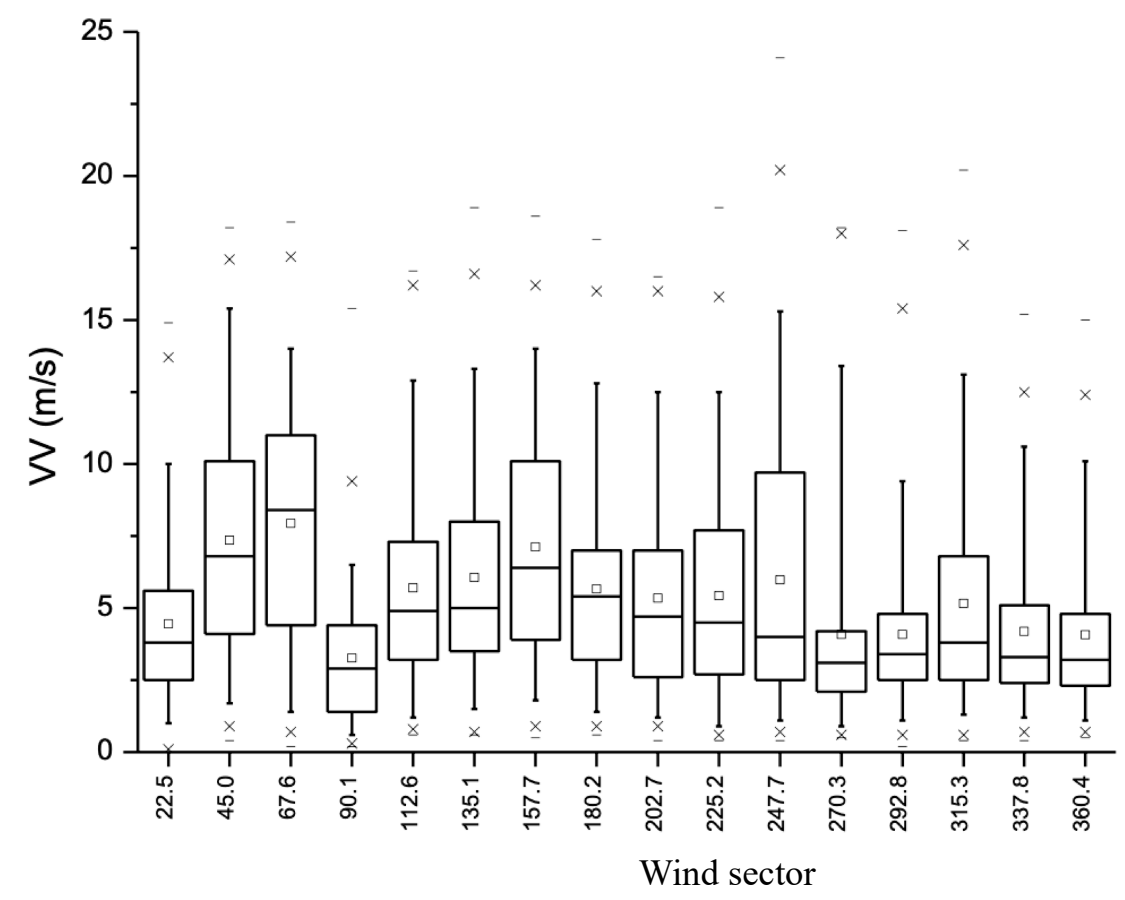

Figure 3. Distribution of wind speeds for each wind sector.

\subsection{Atmospheric Deposition}

\subsubsection{Annual Deposition Rates}

The atmospheric deposition investigation was carried out on four locations taking into account the characteristics of the territory under study. Each sampling system consists of two deposimeters ( 1 for organic fraction and 1 for inorganic) to carry out the analytical determinations of organic and inorganic chemical contaminants in the airborne particle deposition. The analysis was performed for determining organic, i.e., PCDD/Fs, DL-PCBs and PAHs, and inorganic-metal, i.e., $\mathrm{As} \mathrm{Ba} \mathrm{Be} \mathrm{Cd} \mathrm{Co}$, total $\mathrm{Cr}, \mathrm{Cu}, \mathrm{Mn}, \mathrm{Ni}, \mathrm{Pb}, \mathrm{Sb}$, Se, $\mathrm{Sn}, \mathrm{Sr}$, $\mathrm{Te}, \mathrm{Ti}, \mathrm{Tl}, \mathrm{V}, \mathrm{Zn}$, micro-pollutants.

Table 1 summarizes the main regulation developed by various European countries [32] both on atmospheric deposition rate and on the content of PCDD/Fs + DL-PCBs and on some metals.

Table 1. Reference values of deposition rates for dust, some metals and PCDD/Fs + DLPCBs in some European legislations [32].

\begin{tabular}{|c|c|c|c|c|c|c|c|c|c|c|}
\hline & \multirow[t]{2}{*}{ Dust $^{1}$} & \multirow[t]{2}{*}{ As $^{2}$} & \multirow[t]{2}{*}{$\mathrm{Cd}^{2}$} & \multirow{2}{*}{$\mathrm{Hg}^{2}$} & \multirow[t]{2}{*}{$\mathrm{Ni}^{2}$} & \multirow{2}{*}{$\mathrm{Pb}^{2}$} & \multirow[t]{2}{*}{$\mathrm{Tl}^{2}$} & \multirow{2}{*}{$\mathrm{Zn}^{2}$} & \multicolumn{2}{|c|}{$\begin{array}{c}\text { PCDD/Fs + } \\
\text { DL-PCBs }\end{array}$} \\
\hline & & & & & & & & & Monthly $^{3}$ & Annual $^{3}$ \\
\hline Austria & 210 & - & 2 & - & - & 100 & - & - & - & - \\
\hline Belgium & 350 & - & 2 & - & - & 250 & - & - & 21 & 8.2 \\
\hline Croatia & 350 & 4 & 2 & 1 & 15 & 100 & 2 & - & & \\
\hline Germany & 350 & 4 & 2 & 1 & 15 & 100 & 2 & - & - & 4 \\
\hline UK & 200 & ${ }_{-}$ & - & ${ }_{-}$ & - & - & - & _- & - & - \\
\hline Switzerland & 200 & - & 2 & - & - & 100 & 2 & 400 & - & - \\
\hline Slovenia & 200 & - & 2 & - & - & 100 & - & 400 & - & - \\
\hline
\end{tabular}

${ }^{1}$ Expressed as $\mathrm{mg} \mathrm{m}{ }^{-2} \mathrm{~d}^{-1} ;{ }^{2}$ as $\mu \mathrm{g} \mathrm{m} \mathrm{m}^{-2} \mathrm{~d}^{-1} ;{ }^{3} \mathrm{pg}$ WHO-TE $1998 \mathrm{~m}^{-2} \mathrm{~d}^{-1}$.

Table S2 of the Supplementary Material shows the measurements of the deposition rate of the total sedimentable dusts for each location and season. This measure is an important indicator of particular local environmental conditions, such as fouling, deposit on crops and soil, with possible exposure of the population by ingestion, etc., which is given increasing attention. 
European and national legislation does not indicate limit values for the deposition rate of sedimentable dusts. Consequently, an assessment of the extent of the phenomenon can be obtained by comparison with reference values or limits suggested in guidelines or in legislative acts of other European countries (Table 1) [32].

The deposition rates based on monthly collecting period, measured at the Allumiere, S. Agostino, Roccaccia and Rocca Respampani stations, vary between $8.1 \mathrm{mg} \mathrm{m}^{-2} \mathrm{~d}^{-1}$ recorded in the autumn 2015 season at the Roccaccia station, to the $49.3 \mathrm{mg} \mathrm{m}^{-2} \mathrm{~d}^{-1}$ recorded in the spring 2016 season again in Roccaccia (Table S1 of the Supplementary Material).

On the other hand, the deposition rates based on annual collecting period measured in the entire period in the four stations, are, respectively, reported in Table 2.

Table 2. Deposition rate (expressed as $\mathrm{mg} \mathrm{m}^{-2} \mathrm{~d}^{-1}$ ) of the total sedimentable dusts in each location.

\begin{tabular}{ccccc}
\hline Season & Roccaccia & S. Agostino & Allumiere & Rocca Resp. \\
\hline Annual & 21.5 & 35.8 & 18.8 & 27.9 \\
\hline
\end{tabular}

The analysis of these data shows that the stations do not show areas with high rates of atmospheric deposition of total sedimentable dusts, compared to what is reported both in the legislation of different countries and in the scientific literature.

Autumn has the lowest dustiness in all locations, while the Allumiere location, also the winter season, is associated with low dustiness. Spring appears to be the season with the highest dustiness in all locations. In fact, a seasonal variability can be observed that sees the atmospheric depositions of total sedimentable dusts increase, when passing from the humid season to the drier one. This trend can be explained by the greater contribution to the total depositions brought about by the rising phenomena of the total sedimentable dusts from the ground.

The measured total sedimentable dusts rates show both short and long-term (annual average) values that are approximately one order of magnitude lower than the more restrictive limits $\left(200 \mathrm{mg} \mathrm{m}^{-2} \mathrm{~d}^{-1}\right)$ reported in Table 1 by some countries.

\subsubsection{PCDD/Fs and DL-PCBs}

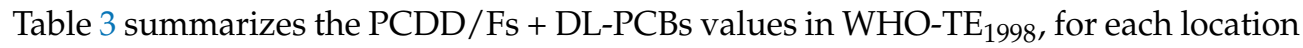
and season. The estimated annual value is also reported on the basis of seasonal data (Table S3 of the Supplementary Material).

Table 3. Mean atmospheric deposition rate (expressed as pg WHO-TE $1998 \mathrm{~m}^{-2} \mathrm{~d}^{-1}$ ) of PCDD/Fs + DL-PCBs by season and location.

\begin{tabular}{ccccc}
\hline Season & Roccaccia & S. Agostino & Allumiere & Rocca Resp. \\
\hline Summer & 14.1 & 0.33 & 0.39 & 1.04 \\
Autumn & 0.90 & 2.70 & 0.29 & 0.82 \\
Winter & 0.53 & 0.33 & 0.59 & 0.27 \\
Spring & 0.19 & 0.21 & 0.14 & 0.16 \\
Annual average & $\mathbf{3 . 9 3}$ & $\mathbf{0 . 8 9}$ & $\mathbf{0 . 3 5}$ & $\mathbf{0 . 5 7}$ \\
\hline
\end{tabular}

The comparison of the deposition rates for the PCDD/Fs + DL-PCBs shows a substantial homogeneity among the sampling sites with the exception of Roccaccia where the mean deposition rate is from 4 to 11 times higher, with a maximum in summer. These average deposition rates are significantly lower than the limit ones envisaged in the legislation and guidelines of various European countries [32]. In particular, in Germany the guide values for PCDD/F and DL-PCBs in deposition define a target value (annual average) of $4 \mathrm{pg}$ WHO-TE $1998 \mathrm{~m}^{-2} \mathrm{~d}^{-1}$, and $9 \mathrm{pg}$ WHO-TE $1998 \mathrm{~m}^{-2} \mathrm{~d}^{-1}$ is the reference for some industrial areas. In the Roccaccia and Allumiere stations, the highest concentrations of PCDD/Fs are recorded in winter and autumn seasons with much lower concentrations in summer and 
spring. S. Agostino shows the highest total PCDD/F concentrations in spring and autumn. Rocca Respampani shows the highest concentrations in winter, but the values are still more comparable between the different seasons. The Roccaccia station is the one that shows a significantly higher value (in WHO-TE).

Table 4 shows the average rates profile of such micropollutants, expressed as fg m $\mathrm{m}^{-2} \mathrm{~d}^{-1}$ and in equivalent toxicity (WHO-TE ${ }_{1998}$ ). Tables S4-S7 of the Supplementary Material report the data of the PCDD/F and DL-PCB rates profiles in each season and location, expressed both in $\mathrm{fg} \mathrm{m}^{-2} \mathrm{~d}^{-1}$ and in equivalent toxicity with respect to the International Toxicity Equivalent (I-TE) factors, WHO-TE 1998 and WHO-TE 2005 .

Table 4. Mean annual levels of PCDD/Fs and DL-PCBs determined in the four investigated locations.

\begin{tabular}{|c|c|c|c|c|c|c|c|c|}
\hline \multirow[b]{2}{*}{ Congener } & \multicolumn{2}{|c|}{ Roccaccia } & \multicolumn{2}{|c|}{ Rocca Respampani } & \multicolumn{2}{|c|}{ Allumiere } & \multicolumn{2}{|c|}{ S. Agostino } \\
\hline & $f g m^{-2} d^{-1}$ & $\begin{array}{l}\text { WHO- } \\
\text { TE}_{1998}\end{array}$ & $f g m^{-2} d^{-1}$ & $\begin{array}{l}\text { WHO- } \\
\text { TE}_{1998}\end{array}$ & $f g m^{-2} d^{-1}$ & $\begin{array}{l}\text { WHO- } \\
\text { TE}_{1998}\end{array}$ & $f g m^{-2} d^{-1}$ & $\begin{array}{l}\text { WHO- } \\
\text { TE}_{1998}\end{array}$ \\
\hline $\begin{array}{l}2,3,7,8- \\
\text { TCDD }\end{array}$ & 38.0 & 38.0 & 15.4 & 15.4 & 15.4 & 15.4 & 24.8 & 24.8 \\
\hline $\begin{array}{l}1,2,3,7,8- \\
\text { PCDD }\end{array}$ & 509 & 509 & 15.4 & 15.4 & 29.1 & 29.1 & 15.4 & 15.4 \\
\hline $\begin{array}{c}1,2,3,4,7,8- \\
\mathrm{HxCDD}\end{array}$ & 399 & 39.9 & 15.4 & 1.54 & 22.1 & 2.21 & 15.4 & 1.54 \\
\hline $\begin{array}{c}\text { 1,2,3,6,7,8- } \\
\mathrm{HxCDD}\end{array}$ & 609 & 60.6 & 36.5 & 3.65 & 31.4 & 3.14 & 38.2 & 3.82 \\
\hline $\begin{array}{c}\text { 1,2,3,7,8,9- } \\
\text { HxCDD }\end{array}$ & 218 & 21.7 & 27.8 & 2.78 & 46.3 & 4.62 & 15.4 & 1.54 \\
\hline $\begin{array}{c}\text { 1,2,3,4,6,7,8- } \\
\text { HpCDD }\end{array}$ & 8513 & 85.1 & 417 & 4.17 & 498 & 4.98 & 489 & 4.89 \\
\hline OCDD & 137.09 & 13.7 & 4023 & 0.402 & 5533 & 0.552 & 5630 & 0.565 \\
\hline $\begin{array}{l}2,3,7,8- \\
\text { TCDF }\end{array}$ & 419 & 41.9 & 119 & 11.9 & 134 & 13.4 & 99.2 & 9.92 \\
\hline $\begin{array}{l}\text { 1,2,3,7,8- } \\
\text { PCDF }\end{array}$ & 810 & 40.5 & 67.3 & 3.36 & 76.1 & 3.81 & 45.8 & 2.29 \\
\hline $\begin{array}{l}2,3,4,7,8- \\
\text { PCDF }\end{array}$ & 1033 & 516 & 69.7 & 34.9 & 96.4 & 48.2 & 44.2 & 22.1 \\
\hline $\begin{array}{c}1,2,3,4,7,8- \\
\text { HxCDF }\end{array}$ & 1173 & 117 & 72.9 & 7.29 & 155 & 15.6 & 64.6 & 6.46 \\
\hline $\begin{array}{c}1,2,3,6,7,8- \\
\mathrm{HxCDF}\end{array}$ & 1199 & 119 & 71.0 & 7.10 & 95.1 & 9.51 & 62.0 & 6.2 \\
\hline $\begin{array}{c}2,3,4,6,7,8- \\
\mathrm{HxCDF}\end{array}$ & 637 & 63.7 & 84.7 & 8.48 & 140 & 14.0 & 75.3 & 7.53 \\
\hline $\begin{array}{c}1,2,3,7,8,9- \\
\mathrm{HxCDF}\end{array}$ & 27.2 & 2.72 & 29.9 & 2.99 & 34.5 & 3.45 & 15.4 & 1.54 \\
\hline $\begin{array}{c}1,2,3,4,6,7,8- \\
\text { HpCDF }\end{array}$ & 2231 & 22.3 & 245 & 2.45 & 768 & 7.69 & 283.9 & 2.84 \\
\hline $\begin{array}{c}\text { 1,2,3,4,7,8,9- } \\
\text { HpCDF }\end{array}$ & 49.2 & 0.492 & 27.0 & 0.270 & 48.9 & 0.487 & 24.5 & 0.245 \\
\hline OCDF & 2899 & 0.287 & 1155 & 0.117 & 1222 & 0.122 & 690 & 0.0675 \\
\hline Total & 158,072 & 1694 & 6493 & 122 & 8947 & 207 & 7634 & 112 \\
\hline 77-CB & 127,165 & 12.7 & 25,277 & 2.53 & 12,750 & 176 & 44,216 & 4.42 \\
\hline $81-\mathrm{CB}$ & 3814 & 0.382 & 765 & 0.078 & 12,750 & 1.27 & 44,216 & 0.240 \\
\hline 105-CB & $3,9632,69$ & 396 & 652,429 & 65.2 & 445 & 0.045 & 2405 & 116 \\
\hline $114-\mathrm{CB}$ & 336,172 & 168 & 52,101 & 26.0 & 301,770 & 30.2 & $1,169,450$ & 53.9 \\
\hline 118-CB & $1,399,6455$ & 1399 & $2,265,709$ & 227 & 9780 & 4.89 & 10,7856 & 487 \\
\hline 123-CB & $1,145,574$ & 114 & 890,431 & 89.0 & 954,798 & 95.5 & $4,873,182$ & 29.5 \\
\hline 126-CB & 893 & 89.3 & 154 & 15.4 & 48,220 & 4.82 & 294,745 & 47.405 \\
\hline 156-CB & 108,006 & 54.0 & 46,223 & 23.1 & 154 & 15.4 & 474 & 28.3 \\
\hline 157-CB & 1443 & 0.722 & 769 & 0.385 & 46,336 & 23.2 & 56,507 & 0.697 \\
\hline 167-CB & 48,895 & 0.488 & 14,061 & 0.140 & 1088 & 0.545 & 1396 & 0.222 \\
\hline 169-CB & 280 & 2.80 & 154 & 1.53 & 12,630 & 0.125 & 22,097 & 2.96 \\
\hline 189-CB & 1568 & 0.155 & 769 & 0.077 & 154 & 1.54 & 296 & 0.167 \\
\hline Total & $19,733,537$ & 2239 & $3,948,844$ & 450 & 1159 & 0.117 & 1669 & 772 \\
\hline
\end{tabular}


In Roccaccia, the predominant contributions are from OCDD which range from 36$96 \%$, depending on the season, with the highest percentage in winter and autumn; in S. Agostino from $64 \%$ to $84 \%$, with the greatest contribution in autumn and spring; in Allumiere from $44 \%$ to $77 \%$ with the highest contribution in autumn and in Rocca Respampani site a variable contribution from $47 \%$ to $75 \%$ with the highest values in autumn and spring. Heptachlorodibenzo- $p$-dioxin (HpCDD) and PCDF are the other congeners that contribute significantly to the rate profiles even if with very variable percentage contributions.

Many reports, studies and/or communications reporting in the scientific literature describe data on PCDD/F levels in Bulk sedimentable dust deposition: Table 5 shows a comparison among different sites across Italy and Europe.

Table 5. Comparison of PCDD/F levels (pg I- TE $\mathrm{m}^{-2} \mathrm{~d}^{-1}$ ) in deposition rates among our values and other studies in different Italian and European locations.

\begin{tabular}{|c|c|c|}
\hline Locations & PCDD/Fs & Ref. \\
\hline $\begin{array}{c}\text { Aosta } \\
\text { (North-West Italy) }\end{array}$ & $\begin{array}{l}\text { urban sites: } 0.6-3.0 \\
\text { industrial sites: } 3.7\end{array}$ & [56] \\
\hline $\begin{array}{c}\text { Venice } \\
\text { (North-East Italy) }\end{array}$ & $\begin{array}{l}\text { urban sites: } 13-200 \\
\text { industrial sites: } 15-2767\end{array}$ & [21] \\
\hline $\begin{array}{l}\text { Mantua }^{\mathrm{a}} \\
\text { (North Italy) }\end{array}$ & $\begin{array}{l}\text { urban site: } 1.2-4.2 \\
\text { industrial site: } 1.3-5.1 \\
\text { rural area: } 1.3-2.7\end{array}$ & [57] \\
\hline $\begin{array}{l}\text { Stroncone-Terni } \\
\text { (Central Italy) }\end{array}$ & urban site: $<5.0$ & [58] \\
\hline $\begin{array}{c}\text { Taranto } \\
\text { (South Italy) }\end{array}$ & $\begin{array}{l}\text { industrial site: } 0.57-45 \\
\text { rural sites: } 1.6-33\end{array}$ & [59] \\
\hline $\begin{array}{c}\text { Melfi }^{\mathrm{a}} \\
\text { (South Italy) }\end{array}$ & $\begin{array}{l}\text { industrial site: } 1.7-2.1 \\
\text { rural area: } 1.2-2.7\end{array}$ & {$[32,60]$} \\
\hline Belgium & $\begin{array}{l}\text { urban site: }<1-12 \\
\text { rural area: }<1-3.1\end{array}$ & [61] \\
\hline Germany & $\begin{array}{l}\text { urban site: }<0.5-464 \\
\text { rural area:7-17 }\end{array}$ & {$[62,63]$} \\
\hline UK & $\begin{array}{l}\text { urban site: }<1-312 \\
\text { rural area: } 0-517\end{array}$ & [33] \\
\hline Denmark & $\begin{array}{l}\text { urban site: } 300-31,600 \\
\text { rural area: } 300-1700\end{array}$ & {$[64,65]$} \\
\hline France & $\begin{array}{l}\text { urban site: } 100-147 \\
\text { rural area: } 20-50\end{array}$ & [66] \\
\hline $\begin{array}{l}\text { North Latium } \\
\text { (Central Italy) }\end{array}$ & $\begin{array}{l}\text { urban site: } 1.4-7.1 \\
\text { industrial site: } 1.4-4.6 \\
\text { rural area: } 1.4-3.9\end{array}$ & This study \\
\hline
\end{tabular}

a site with presence of an incineration plant.

\subsubsection{PAHs}

The annual average deposition rates of each $\mathrm{PAH}$ measured at the four sites are shown in Table 6 while the seasonal variability is illustrated in Figure 4. Table S8 of the Supplementary Material reports the deposition rates of each PAH by season. 
Table 6. Mean annual PAH levels $\left(\mathrm{ng} \mathrm{m}^{-2} \mathrm{~d}^{-1}\right)$ determined in the four investigated locations.

\begin{tabular}{ccccc}
\hline Compound & Roccaccia & $\begin{array}{c}\text { Rocca } \\
\text { Respampani }\end{array}$ & Allumiere & S. Agostino \\
\hline Benz[a]Anthracene & 3.593 & 4.515 & 6.268 & 2.510 \\
Benzo[b]Fluoranthene & 4.760 & 100.493 & 6.320 & 2.587 \\
Benzo[j]Fluoranthene & 4.995 & 1.538 & 3.403 & 1.538 \\
Benzo[k]Fluoranthene & 3.763 & 1.538 & 3.190 & 3.325 \\
Benzo[a]Pyrene & 5.873 & 2.325 & 3.950 & 2.165 \\
Dibenzo[a,h]Anthracene & 1.553 & 1.538 & 1.538 & 1.538 \\
Dibenzo[a,e]Pyrene & 2.073 & 1.538 & 1.538 & 1.538 \\
Dibenzo[a,h]Pyrene & 1.553 & 1.538 & 1.538 & 1.538 \\
Dibenzo[a,i]Pyrene & 2.323 & 1.538 & 1.538 & 1.538 \\
Dibenzo[a,l]Pyrene & 1.553 & 1.538 & 1.538 & 1.538 \\
Indeno[1,2,3-cd]Pyrene & 4.853 & 1.538 & 2.428 & 1.538 \\
Acenaphthene & 34.663 & 7.178 & 212.348 & 11.710 \\
Acenaphthylene & 36.023 & 9.028 & 18.228 & 16.213 \\
Anthracene & 13.465 & 10.295 & 7.953 & 6.145 \\
Benzo[g,h,i]Perilene & 5.670 & 1.538 & 4.695 & 1.538 \\
Crysene & 6.228 & 4.193 & 9.175 & 4.065 \\
Phenanthrene & 103.723 & 77.238 & 72.873 & 51.878 \\
Fluoranthene & 14.000 & 8.473 & 15.990 & 10.693 \\
Fluorene & 84.898 & 78.830 & 88.820 & 47.730 \\
Naphthalene & 164.510 & 67.385 & 103.665 & 68.620 \\
Pyrene & 11.433 & 7.058 & 15.128 & 7.745 \\
Total PAHs & $\mathbf{5 1 1 . 4 9 8}$ & $\mathbf{3 9 0 . 8 5 3}$ & $\mathbf{5 8 2 . 1 1 8}$ & $\mathbf{2 4 7 . 6 9 0}$ \\
\hline
\end{tabular}
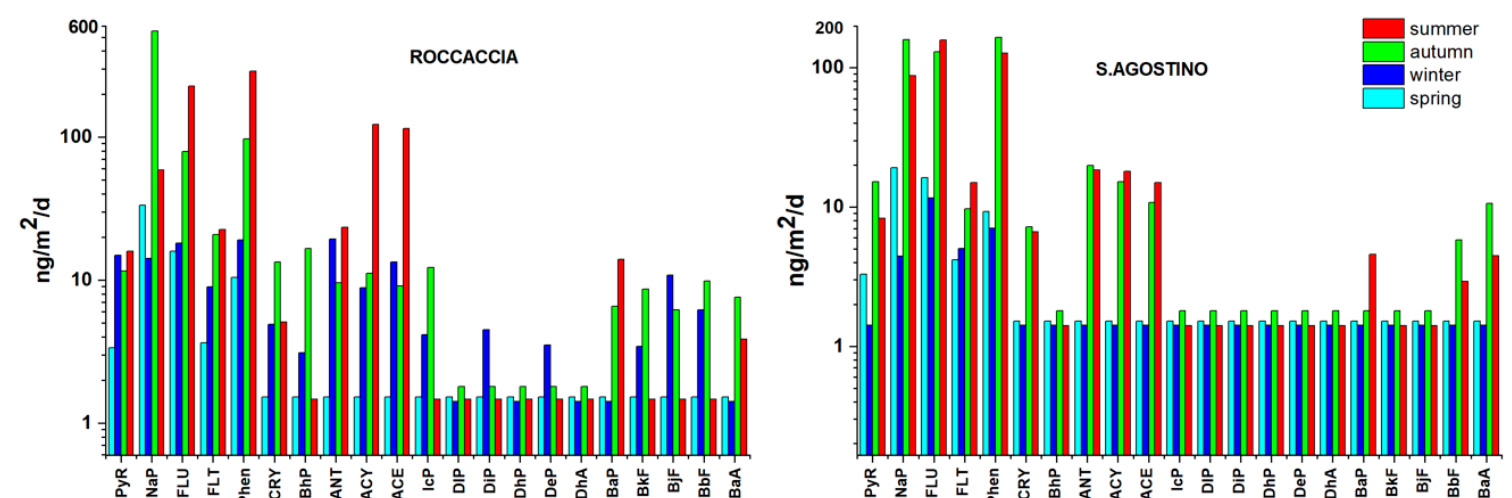

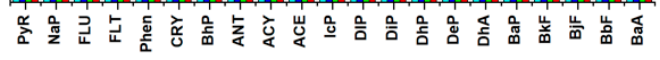
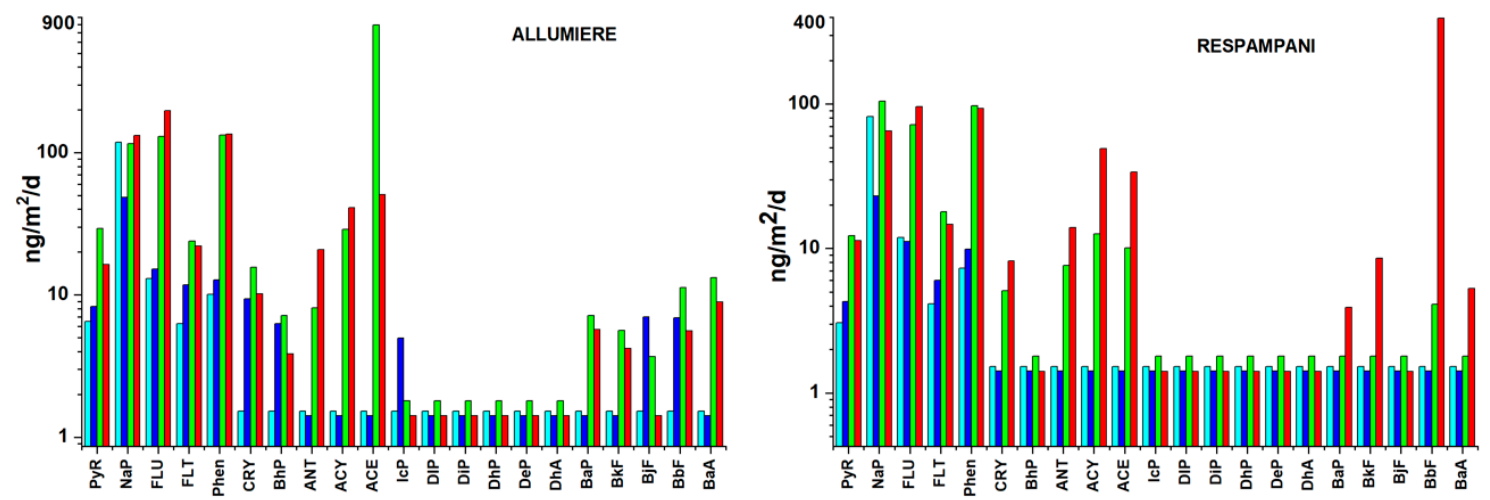

Figure 4. Concentrations (expressed as $\mathrm{ng} \mathrm{m}^{-2} \mathrm{~d}^{-1}$ ) of each PAH in the deposition rates in the four locations for each season. For the acronyms: BaA Benzo[a]Anthracene; BbF Benzo[b]Fluoranthene; BjF Benzo[j]Fluoranthene; BkF Benzo[k]Fluoranthene; BaP Benzo[a]Pyrene; DhA Dibenzo[a,h]Anthracene; DeP Dibenzo[a,e]Pyrene; DhP Dibenzo[a,h]Pyrene; DiP Dibenzo[a,i]Pyrene; DIP Dibenzo[a,1]Pyrene; IcP Indeno[1,2,3-cd]Pyrene; ACE Acenaphthene; ACY Acenaphthylene; ANT Anthracene; BhP Benzo[g,h,i]Perylene; CRY Chrisene; Phen Phenanthrene; FLT Fluoranthene; FLU Fluorene; NaP Naphtalene; PyR Pyrene. 
As already observed in the previous study [67], the highest contribution is due to the lighter PAHs. In atmospheric deposition, the heavier PAHs (i.e., over benzo[a]pyrene, B[a]P, molecular weight, 252.32 Da) are observed with higher frequencies than those detected in $\mathrm{PM}_{2.5}$ and $\mathrm{PM}_{10}$ fractions. The background station of Rocca Respamani records, on average, lower PAH rates than the other stations, with the exception of a single observation of benzo(b)fluoranthene in summer [68] which is very high compared to all other stations during all sampling periods.

$\mathrm{B}[\mathrm{a}] \mathrm{P}$ was selected as a marker of the carcinogenic potencies of the six PAHs (i.e., Benzo[a]Anthracene, Benzo[b]Fluoranthene, Benzo[j]Fluoranthene, Benzo[k]Fluoranthene, Indeno[1,2,3-cd] Pyrene and Dibenzo[ah]Anthracene) [22,69-72].

The comparison of the deposition rates for $\mathrm{B}[\mathrm{a}] \mathrm{P}$ in the four sites (Table 6 ) shows a substantial homogeneity of the annual average rates recorded in the Roccaccia and Allumiere sites which are, respectively, equal to 5.9 and $3.9 \mathrm{ng} \mathrm{m}^{-2} \mathrm{~d}^{-1}$, and significantly lower deposimetric rates in the S. Agostino $2.3 \mathrm{ng} \mathrm{m}^{-2} \mathrm{~d}^{-1}$ and Rocca Respampani $2.2 \mathrm{ng} \mathrm{m}^{-2} \mathrm{~d}^{-1}$ stations, which constitutes the blank site. These annual average deposition rates are in line with those measured in remote/reference and urban Italian areas (see Table 7).

Table 7. Levels of B[a]P in other studies in different Italian and European locations $\left(\mathrm{ng} \mathrm{m}^{-2} \mathrm{~d}^{-1}\right)$.

\begin{tabular}{|c|c|c|}
\hline Locations & Benzo[a]Pyrene & Ref. \\
\hline $\begin{array}{c}\text { Aosta } \\
\text { (North-West Italy) }\end{array}$ & $\begin{array}{l}\text { urban site: } 28 \\
\text { reference site: } 5.0\end{array}$ & {$[57,73]$} \\
\hline $\begin{array}{c}\text { Venice } \\
\text { (North-East Italy) }\end{array}$ & $\begin{array}{l}\text { urban site: } 30 \\
\text { rural area: } 6-9\end{array}$ & [21] \\
\hline $\begin{array}{c}\text { Perugia } \\
\text { (Central Italy) }\end{array}$ & urban site: $5.0-14$ & [74] \\
\hline $\begin{array}{c}\text { Terni } \\
\text { (Central Italy) }\end{array}$ & $\begin{array}{l}\text { urban sites: } 10-11 \\
\text { industrial sites: } 18-27\end{array}$ & [74] \\
\hline $\begin{array}{c}\text { Melfi } \\
\text { (South Italy) }\end{array}$ & $\begin{array}{c}\text { urban sites: } 3.2-4.1 \\
\text { industrial sites: } 4.6-6.9 \\
\quad \text { rural site: } 140 \\
\text { remote/reference sites: } 1.9-5.7\end{array}$ & {$[22,32]$} \\
\hline $\begin{array}{c}\text { Taranto } \\
\text { (South Italy) }\end{array}$ & $\begin{array}{l}\text { urban sites: } 2.0-182 \\
\text { industrial site: } 57-555 \\
\text { rural area: } 5.6-42\end{array}$ & [59] \\
\hline Finland $^{\mathrm{a}}$ & $\begin{array}{l}\text { remote sites: } 51-280 \\
\quad \text { rural area: } 2-10\end{array}$ & [17] \\
\hline $\begin{array}{c}\text { Rorvik } \\
\text { (Sweden) }\end{array}$ & rural area: $5-17$ & {$[75]$} \\
\hline $\begin{array}{c}\text { Paris } \\
\text { (France) }\end{array}$ & urban site: 25 & {$[18,19]$} \\
\hline $\begin{array}{c}\text { Cardiff, Manchester }{ }^{a} \\
\text { (UK) }\end{array}$ & urban area: $219-300$ & [33] \\
\hline $\begin{array}{l}\text { North Latium } \\
\text { (Central Italy) }\end{array}$ & $\begin{array}{l}\text { urban site: } 1.4-7.1 \\
\text { industrial site: } 1.4-4.6 \\
\text { rural area: } 1.4-3.9\end{array}$ & This study \\
\hline
\end{tabular}

\subsubsection{Metals}

The atmospheric depositions collected with the deposimeters in the Roccaccia, S. Agostino, Allumiere and Roccarespampani stations were analyzed to determine the deposition rates of the following metals and metalloids which are toxic for human exposure: As, $\mathrm{Ba}, \mathrm{Be}, \mathrm{Cd}, \mathrm{Cu}, \mathrm{Cr}, \mathrm{Mn}, \mathrm{Ni}, \mathrm{Hg}, \mathrm{Pb}, \mathrm{Sb}, \mathrm{Sr}, \mathrm{Sn}, \mathrm{Te}, \mathrm{Tl}, \mathrm{V}$, and $\mathrm{Zn}$. Even with regard to metals and metalloids in depositions, the Italian and European regulations do not provide any 
reference and it is therefore necessary to take into account the reference values adopted by other European countries.

The atmospheric deposition rates measured in the Roccaccia, S. Agostino, Allumiere and Rocca Respampani stations all year long (Table 8 for the annual average whereas Table S9 of the Supplementary Material for each season) show a small variability among seasons with the exception of the Sn in Allumiere and S. Agostino (autumn/spring and winter/summer seasons) and Zn in Roccaccia (autumn/winter season), whose atmospheric deposition rates are significantly higher than in Rocca Respampani. This small seasonal variability shows a different pattern among the sampling sites.

Table 8. Mean levels of metals $\left(\mu \mathrm{g} \mathrm{m}^{-2} \mathrm{~d}^{-1}\right.$ ) determined in the atmospheric depositions at the four investigated locations.

\begin{tabular}{ccccc}
\hline Metals & Roccaccia & Rocca Resp. & Allumiere & S. Agostino \\
\hline $\mathrm{As}$ & 0.073 & 0.084 & 0.441 & 0.409 \\
$\mathrm{Ba}$ & 1.470 & 2.947 & 4.583 & 1.541 \\
$\mathrm{Be}$ & 0.009 & 0.037 & 0.016 & 0.012 \\
$\mathrm{Cd}$ & 0.013 & 0.009 & 0.020 & 0.072 \\
$\mathrm{Co}$ & 0.083 & 0.092 & 0.105 & 0.082 \\
$\mathrm{Cr}$ & 0.452 & 0.435 & 0.758 & 0.588 \\
$\mathrm{Cu}$ & 0.858 & 0.550 & 0.751 & 0.869 \\
$\mathrm{Mn}{ }^{1}$ & 4.773 & 3.266 & 3.581 & 3.034 \\
$\mathrm{Ni}$ & 0.394 & 0.300 & 0.470 & 0.479 \\
$\mathrm{~Pb}$ & 1.105 & 1.452 & 0.921 & 2.553 \\
$\mathrm{Sb}$ & 0.024 & 0.042 & 0.059 & 0.048 \\
$\mathrm{Se}$ & 0.025 & 0.025 & 0.025 & 0.027 \\
$\mathrm{Sn}$ & 12.881 & 14.402 & 17.955 & 113.356 \\
$\mathrm{Sr}$ & 1.519 & 2.998 & 3.534 & 1.592 \\
$\mathrm{Tl}$ & 0.006 & 0.016 & 0.015 & 0.006 \\
$\mathrm{Te}{ }^{1}$ & 0.001 & 0.001 & 0.001 & 0.001 \\
$\mathrm{Ti}$ & 1.227 & 2.181 & 1.327 & 1.292 \\
$\mathrm{~V}$ & 0.375 & 0.487 & 0.592 & 0.531 \\
$\mathrm{Zn}$ & 6.174 & 3.846 & 6.115 & 5.449 \\
$\mathrm{Total}$ & $\mathbf{3 1 . 4 6 0}$ & $\mathbf{3 3 . 1 6 8}$ & $\mathbf{4 1 . 2 6 5}$ & $\mathbf{1 3 1 . 9 4 1}$ \\
\hline
\end{tabular}

1 detected only in winter and spring seasons.

The typical concentrations of metals, detected in different European areas, using bulk deposimeters, are summarized below, considering diverse types of areas [32,76]. The legislations of several European countries establish limit values expressed as an annual average for $\mathrm{As}, \mathrm{Cd}, \mathrm{Hg}, \mathrm{Ni}, \mathrm{Pb}, \mathrm{Tl}, \mathrm{Zn}$ and sedimentable dusts [32]. Table 9 resumes such limit values present in the related various legislations.

Table 9. Limit value concentrations $\left(\mu \mathrm{g} \mathrm{m}^{-2} \mathrm{~d}^{-1}\right)$ reported in European legislation for different areas.

\begin{tabular}{cccc}
\hline \multirow{2}{*}{ Metals } & \multicolumn{3}{c}{ Type of Area } \\
\cline { 2 - 4 } & Rural & Urban & Industrial \\
\hline $\mathrm{As}$ & $0.082-0.43$ & $0.22-3.4$ & $2.0-4.3$ \\
$\mathrm{Cd}$ & $0.011-0.14$ & $0.16-0.90$ & $0.12-4.6$ \\
$\mathrm{Ni}$ & $0.03-4.3$ & $5-11$ & $2.3-22$ \\
\hline
\end{tabular}

The comparison of the atmospheric depositions rates observed in this study with the limit values shown in Table 9 [32] describes an area in the lower ranges of the atmospheric deposition values as expected in the different countries. Using the intervals rates suggested by the European Commission, the monitored sites of this study would be classified as rural areas for $\mathrm{Ni}$ and $\mathrm{Cd}$, and urban for As. 


\subsection{Chemometric Approach}

A chemometric investigation has been carried out on the average deposition rates of annual collecting data, for a better knowledge of the relationships among the main species occurring in the deposition rates. Cluster analysis (CA) and principal component analysis (PCA) were used to achieve similarities among the different species as well as for understanding how the dataset can be divided [77-79]. First, CA among the data of each location was run. As it can be seen in Figure 5, data collected at the two locations such as Rocca Respampani and Allumiere show high similarities whereas ones collected at $\mathrm{S}$. Agostino site show very high dissimilarity in comparison with the previous ones. Roccaccia has an intermediate behavior among the sites.

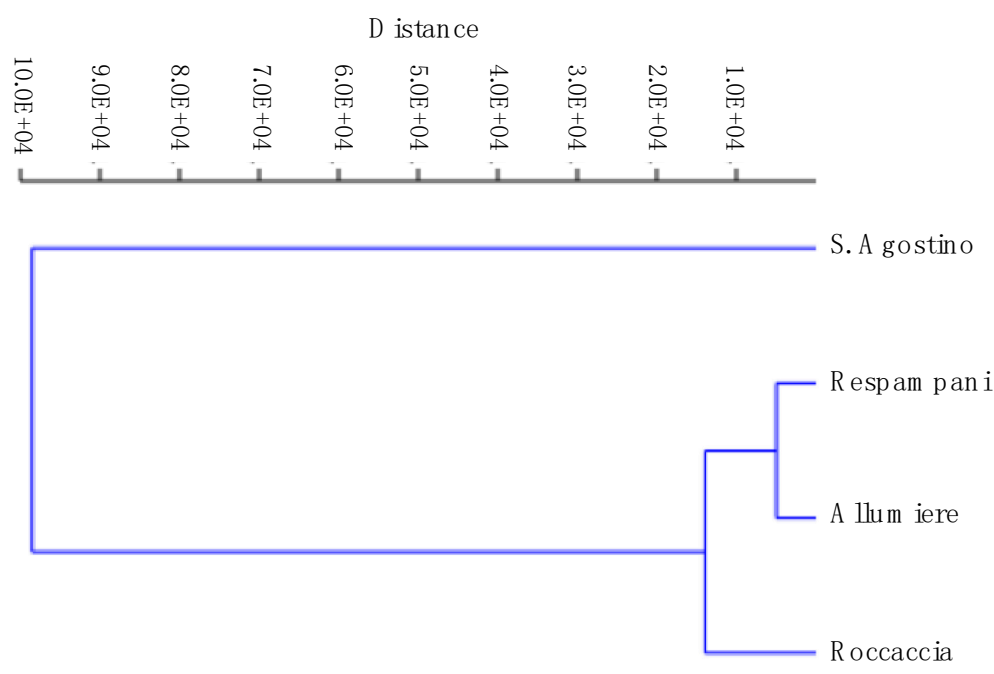

Figure 5. Cluster Analysis (CA) related to the different sampling points.

This behavior can be explained taking into account both the four sampling points (Figure 1) and the direction of the prevailing winds, i.e., North-West and South-East (Figure 2). The S. Agostino site is located both close to the power plant and close to the port-industrial area in Civitavecchia [67] whereas Allumiere and Rocca Respampani are in the inner part of the region, far from the anthropogenic sources. Roccaccia is located north of S. Agostino, along the same direction as the prevailing winds but farther from anthropogenic sources, i.e., power plant and port-industrial area. These occurrences can explain the Allumiere and Rocca Respampani profiles cluster as well as Roccaccia one whereas S. Agostino is totally different.

The authors would like to investigate the overall data (inorganic and organic fractions) both for finding out similarities among the different species and for evidencing possible presence of outliers that could affect the analysis. First, the CA shows the presence of three clusters:

cluster \# 11 compound: Sn;

cluster \# 25 compounds: 118-CB, Ba, Mn, Sr, Zn;

cluster \# 362 compounds: all other compounds/elements.

For a better representation, the authors would like to show the PCA (Figure 6): the three clusters are well evidenced with the related species. 


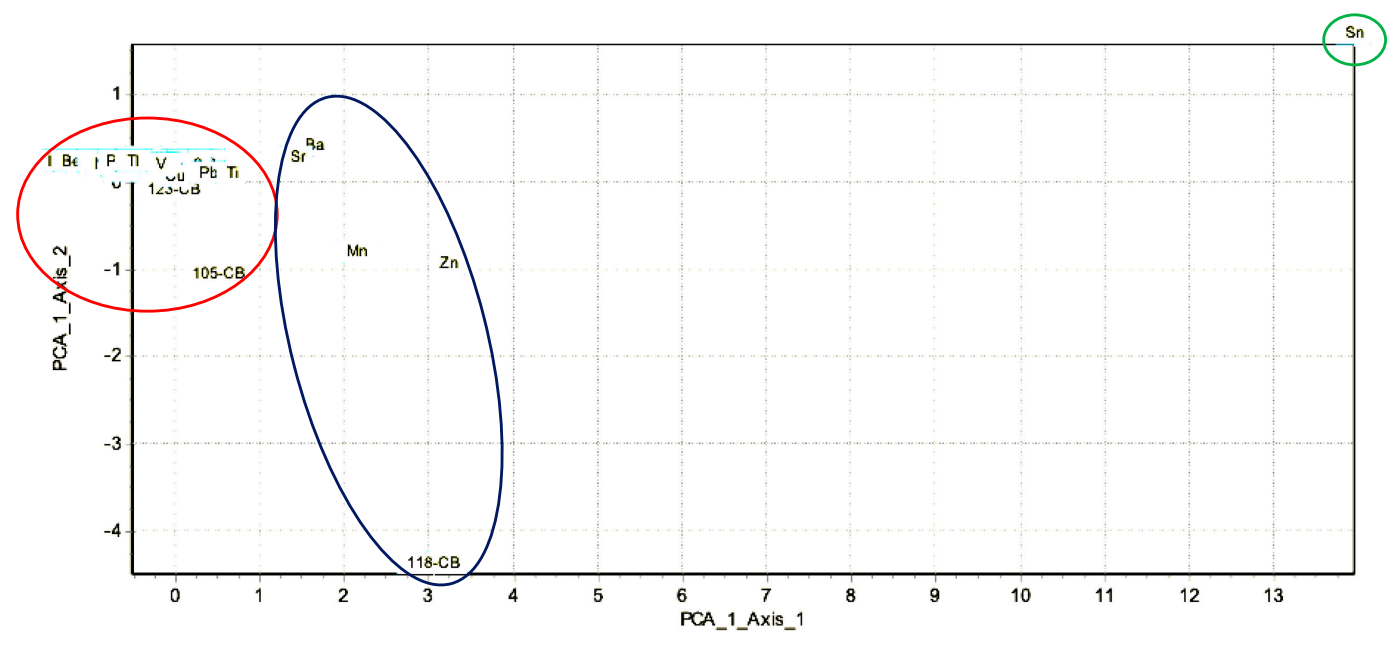

Figure 6. Principal Component Analysis (PCA) of the overall data. Component 1: organic fraction; Component 2: inorganic fraction.

As it can be seen, the only different species is $\mathrm{Sn}$, which makes group by itself and very distant from the other clusters. In these conditions, Sn could be considered an outlier: this consideration is confirmed looking at the data reported in Table 8 where Sn concentration value determined at $\mathrm{S}$. Agostino site reaches high annual average level $\left(113 \mu \mathrm{g} \mathrm{m}^{-2} \mathrm{~d}^{-1}\right)$. The data reported in Table S8 of the Supplementary Material confirm and stress this consideration. The data determined in summer and autumn seasons are 100 to 12,000 times higher than those determined in the other seasons; further, the seasonal values greatly range among them, with a very high level in autumn $\left(449 \mu \mathrm{g} \mathrm{m}^{-2} \mathrm{~d}^{-1}\right)$ at S. Agostino site. These factors lead to the hypothesis that $S n$ could be considered an outlier. Following this assumption, the PCA among sites was performed using all the data but omitting the Sn values, as shown in Figure 7. Component 1 represents the organic fraction, distinguished in the positive values associated with PCBs (mainly, 118-CB, 105-CB, 123-CB, 114-CB) and $\mathrm{PCDD} / \mathrm{Fs}$ (mainly, OCDD) and the negative values associated with PAHs: Roccaccia is the station with the highest content of PCDD/Fs and PCBs, while Allumiere is the station with the highest values of PAHs and S. Agostino is the one with the lowest contribution of organic compounds. Component 2 represents the inorganic fraction (mainly, Ba, $\mathrm{Zn}, \mathrm{Sr}$, $\mathrm{Mn}$ ): once again, Allumiere shows the highest metal content.

This finding could be reasonable considering the map reported in Figure 1, and especially the distance among the emission points, i.e., the power plant and the portindustrial area of Civitavecchia, and each sampling site: Roccaccia and Rocca Respampani, which are further away from these points than the other two locations, are the main receptors of the organic compounds according to the wind direction whereas the Allumiere and S. Agostino sites mainly suffer of inorganic contamination. 


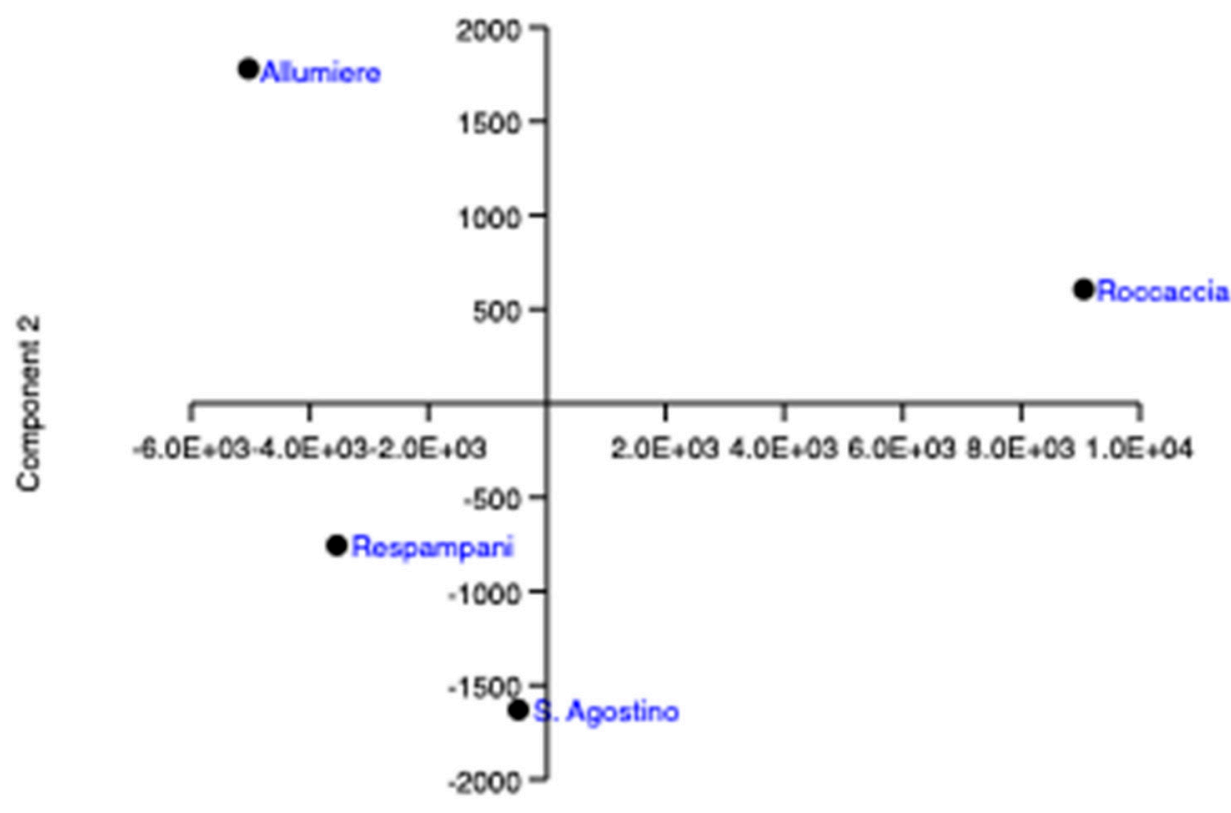

Component 1

Figure 7. PCA of the four investigated locations. Component 1: inorganic fraction; Component 2: organic fraction.

\section{Conclusions}

The monitoring of deposition airborne particle greatly contributes to the knowledge on the dynamic of pollution in an area allowing to study the deposition fluxes, the pollutants environmental fate with the aim to address the potential exposure for population. Total depositions (bulk) are particularly suitable to measure the environmental POPs concentration. The data collected by bulk deposition are useful to estimate contamination of farmlands and a subsequent accumulation in the food chain (in which POPs are particularly associated with to fats). In this study, we want to replicate the approach already used in countries like Belgium, Germany and France for PCDD/Fs and PCBs to identify reference values (TDI/deposition) for the Italian situation. Particularly, the results of the chemical characterization of the depositions show that the major differences between the sites are attributable to the PCDD/Fs content. In fact, the total metal content and the total PAHs one are comparable between the four sites, whereas PCDD/Fs and DL-PCBs between the Roccaccia and Rocca Respanpami sites are 3/4 orders of magnitude higher than the other two locations. This suggests that what has been observed is due to activities carried out locally, probably attributable to livestock and agricultural activities. This is conceivable by observing the seasonal differences in the content of PCDD/Fs and DL-PCDs in the different sites: in fact, higher contributions of PCDD/Fs and DL-PCBs in the depositions are observed mainly in summer and autumn. Even the meteorological characteristics of the summer may have contributed to the increase in these depositions. Furthermore, it is highlighted that the results of the chemical characterization of the depositions do not distinguish the potential contribution due to the CTE plant, unlike the results of the airborne PM chemical characterization study [67], performed in the same area. At present, it is necessary to establish specific guidelines and/or limits at European level to better manage the particularly difficult environmental and health situations of the population that are observed in the various national contexts. Finally, it is also desirable find a European consensus on sampling procedures, analytical methods and assessment methods for a unique, accurate and effective evaluation approach. 
Supplementary Materials: The following are available online at https://www.mdpi.com/2076-3 417/11/4/1827/s1, Tables S1-S9: Table S1. Limit of Detections (LODs) for each compound/metal determined in this study. LODs were determined according to the methods reported in International guidelines [51-55]; Table S2. Deposition $\left(\mathrm{mg} \mathrm{m}^{-2} \mathrm{~d}^{-1}\right)$ of the total sedimentable particulate matter (PM) per season at each location; Table S3. Atmospheric deposition of PCDD/Fs + DL-PCBs per season at each location; Table S4. Levels of PCDD/Fs and DL-PCBs expressed as equivalent toxicity I-TE, WHO-TE 1998 and WHO-TE 2005 at Roccaccia location; Table S5. Levels of PCDD/Fs and DLPCBs expressed as equivalent toxicity I-TE, WHO-TE 1998 and $\mathrm{WHO}_{\mathrm{T}} \mathrm{TE}_{2005}$ at S. Agostino location; Table S6. Levels of PCDD/Fs and DL-PCBs expressed as equivalent toxicity I-TE, WHO-TE 1998 and WHO-TE 2005 at Allumiere location; Table S7. Levels of PCDD/Fs and DL-PCBs expressed as equivalent toxicity I-TE, WHO-TE 1998 and $\mathrm{WHO}_{2} \mathrm{TE}_{2005}$ at Rocca Respampani location; Table S8. Seasonal levels of the deposition rates $\left(\mathrm{ng} \mathrm{m}^{-2} \mathrm{~d}^{-1}\right)$ for PAHs determined in the four investigated locations; Table S9. Seasonal levels of the deposition rates $\left(\mu \mathrm{g} \mathrm{m}^{-2} \mathrm{~d}^{-1}\right)$ for metals determined in the four investigated locations.

Author Contributions: Conceptualization, M.E.S., G.M. and P.A.; methodology, G.S. and G.M.; software, M.I.; validation, M.I. and G.S.; formal analysis, M.I.; investigation, M.I. and G.S.; resources, G.S.; data curation, M.E.S.; writing-original draft preparation, P.A.; writing-review and editing, G.S., M.E.S. and P.A.; visualization, G.S.; supervision, G.M. and M.E.S.; project administration, G.S.; funding acquisition, G.M. All authors have read and agreed to the published version of the manuscript.

Funding: This research was performed under the agreement between the Italian National Institute of Health (ISS) and the Consortium for the Management of the Environmental Observatory of Civitavecchia, for the realization of a research program having as objective "The evaluation of the levels of organic and inorganic micropollutants in the area of the municipalities of Civitavecchia, Tolfa, Allumiere, Santa Marinella, Monte Romano and Tarquinia affected by emissions from the ENEL thermoelectric power station of Torrevaldaliga North".

Institutional Review Board Statement: Not applicable.

Informed Consent Statement: Not applicable.

Data Availability Statement: All the data are available in the Supplementary Materials.

Acknowledgments: The authors would like to thank Maurizio Manigrasso for his helpful suggestions in the data presentation.

Conflicts of Interest: The authors declare no conflict of interest.

\section{References}

1. Avino, P.; Manigrasso, M. Ten-year measurements of gaseous pollutants in urban air by an open-path analyzer. Atmos. Environ. 2008, 42, 4138-4148. [CrossRef]

2. Costabile, F.; Alas, H.; Aufderheide, M.; Avino, P.; Amato, F.; Argentini, S.; Barnaba, F.; Berico, M.; Bernardoni, V.; Biondi, R.; et al. First Results of the "Carbonaceous Aerosol in Rome and Environs (CARE)" Experiment: Beyond Current Standards for PM10. Atmosphere 2017, 8, 249. [CrossRef]

3. Manigrasso, M.; Vernale, C.; Avino, P. Traffic aerosol lobar doses deposited in the human respiratory system. Environ. Sci. Pollut. Res. 2017, 24, 13866-13873. [CrossRef] [PubMed]

4. Slanina, S.; Piantaz, M.; Wyers, G.P. Deposition: From local measurements to conclusion on a European scale. In Proceedings of the EUROTRAC Symposium '94; Borrel, S., Ed.; SPB Academic Publishing: The Hague, The Netherlands, 1994; pp. $606-613$.

5. European Community. Directive 2004/107/EC of the European Parliament and of the Council of 15 December 2004 relating to arsenic, cadmium, mercury, nickel and polycyclic aromatic hydrocarbons in ambient air. Off. J. Eur. Union 2005, L23, 3-16.

6. Belgium. Royal Decree of 23 April 1998 on maximum levels of dioxin in food. In force from 12 June 1998. Available online: https:/ / ec.europa.eu/environment/archives/dioxin/pdf/dioxin.pdf (accessed on 18 February 2021).

7. Germany. Bericht des Länderausschusses für Immissionsschutz (LAI), Bewertung von Schadstoffen, für die keine Immissionswerte festgelegt sind-Orientierungswerte für die Sonderfallprüfung und für die Anlagenüber-wachung sowie Zielwerte für die langfristige Luftreinhalteplanung unter besonderer Berücksichtigung der Beurteilung krebserzeugender Luftschadstoffe. Vom 21 September 2004. Available online: https:/ / www.lanuv.nrw.de/fileadmin/lanuv/gesundheit/pdf/LAI2004.pdf (accessed on 11 February 2021).

8. Jeffries, D.S.; Snyder, W.R. Atmospheric deposition of heavy metals in central Ontario. Water Air Soil Pollut. 1980, 15, 127-152. [CrossRef] 
9. Morrison, K.A.; Kuhn, E.S.; Watras, C.J. Comparison of three methods of estimating atmospheric mercury deposition. Environ. Sci. Technol. 1995, 29, 571-576. [CrossRef]

10. Azimi, S.; Ludwig, A.; Thévenot, D.R.; Colin, J.-L. Trace metal determination in total atmospheric deposition in rural and urban areas. Sci. Total Environ. 2003, 308, 247-256. [CrossRef]

11. Erisman, J.W.; Mols, H.; Fonteijn, P.; Geusebroek, M.; Draaijers, G.; Bleeker, A.; van der Veen, D. Field intercomparison of precipitation measurements performed within the framework of the Pan European Intensive Monitoring Program of EU/ICP Forest. Environ. Pollut. 2003, 125, 139-155. [CrossRef]

12. Avila, A.; Rodrigo, A. Trace metal fluxes in bulk deposition, throughfall and stemflow at two evergreen oak stands in NE Spain subject to different exposure to the industrial environment. Atmos. Environ. 2004, 38, 171-180. [CrossRef]

13. Aas, W.; Alleman, L.Y.; Bieber, E.; Gladtke, D.; Houdret, J.-L.; Karlsson, V.; Monies, C. Comparison of methods for measuring atmospheric deposition of arsenic, cadmium, nickel and lead. J. Environ. Monit. 2009, 11, 1276-1283. [CrossRef] [PubMed]

14. Bacardit, M.; Camarero, L. Fluxes of Al, Fe, Ti, Mn, Pb, Cd, Zn, Ni, Cu, and As in monthly bulk deposition over the Pyrenees (SW Europe): The influence of meteorology on the atmospheric component of trace element cycles and its implications for high mountain lakes. J. Geophys. Res. 2009, 114, G00D02. [CrossRef]

15. Gunawardena, J.; Egodawatta, P.; Ayoko, G.A.; Goonetilleke, A. Atmospheric deposition as a source of heavy metals in urban stormwater. Atmos. Environ. 2013, 68, 235-242. [CrossRef]

16. Bari, M.A.; Kindzierski, W.B.; Cho, S. A wintertime investigation of atmospheric deposition of metals and polycyclic aromatic hydrocarbons in the Athabasca Oil Sands Region, Canada. Sci. Total Environ. 2014, 485-486, 180-192. [CrossRef]

17. Korhonen, M.; Kiviranta, A.; Ketola, R. Bulk deposition of PAHs, PCBs and HCHs in Finland in summer seasons $1993-1996$. Toxicol. Environ. Chem. 1998, 66, 37-45. [CrossRef]

18. Ollivon, D.; Blanchoud, H.; Motelay-Massei, A.; Garban, B. Atmospheric deposition of PAHs to an urban site, Paris, France. Atmos. Environ. 2002, 36, 2891-2900. [CrossRef]

19. Garban, B.; Blanchoud, H.; Motelay-Massei, A.; Chevreuil, M.; Ollivon, D. Atmospheric bulk deposition of PAHs onto France: Trends from urban to remote sites. Atmos. Environ. 2002, 36, 5395-5403. [CrossRef]

20. Motelay-Massei, A.; Ollivon, D.; Tiphagne, K.; Garban, B. Atmospheric bulk deposition of trace metals to the Seine river Basin, France: Concentrations, sources and evolution from 1988 to 2001 in Paris. Water Air Soil Pollut. 2005, 164, 119-135. [CrossRef]

21. Rossini, P.; Guerzoni, S.; Molinaroli, E.; Rampazzo, G.; De Lazzari, A.; Zancanaro, A. Atmospheric bulk deposition to the lagoon of Venice part I. Fluxes of metals, nutrients and organic contaminants. Environ. Int. 2005, 31, 959-974. [CrossRef]

22. Menichini, E.; Barbera, S.; Merli, F.; Settimo, G.; Viviano, G. Atmospheric bulk deposition of carcinogenic PAHs in a rural area in southern Italy. Polycycl. Aromat. Compd. 2006, 26, 253-263. [CrossRef]

23. Moon, H.-B.; Kannan, K.; Lee, S.-J.; Ok, G. Atmospheric deposition of polycyclic aromatic hydrocarbons in an urban and a suburban area of Korea from 2002 to 2004. Arch. Environ. Contam. Toxicol. 2006, 51, 494-502. [CrossRef] [PubMed]

24. Motelay-Massei, A.; Ollivon, D.; Garban, B.; Tiphagne-Larcher, K.; Zimmerlin, I.; Chevreuil, M. PAHs in the bulk atmospheric deposition of the Seine river basin: Source identification and apportionment by ratios, multivariate statistical techniques and scanning electron microscopy. Chemosphere 2007, 67, 312-321. [CrossRef]

25. Rossini, P.; Matteucci, G.; Raccanelli, S.; Favotto, M.; Guerzoni, S.; Gattolin, M. Polycyclic aromatic hydrocarbons in atmospheric depositions around the Venice lagoon. Polycycl. Aromat. Compd. 2007, 27, 197-210. [CrossRef]

26. Gocht, T.; Klemm, O.; Grathwohl, P. Long-term atmospheric bulk deposition of polycyclic aromatic hydrocarbons (PAHs) in rural areas of Southern Germany. Atmos. Environ. 2007, 41, 1315-1327. [CrossRef]

27. Su, Y.; Wania, F.; Harner, T.; Lei, Y.D. Deposition of polybrominated diphenyl ethers, polychlorinated biphenyls, and polycyclic aromatic hydrocarbons to a boreal deciduous forest. Environ. Sci. Technol. 2007, 41, 534-540. [CrossRef] [PubMed]

28. Esen, F.; Cindoruk, S.S.; Tasdemir, Y. Bulk deposition of polycyclic aromatic hydrocarbons (PAHs) in an industrial site of Turkey. Environ. Pollut. 2008, 152, 461-467. [CrossRef]

29. Wang, W.; Simonich, S.L.M.; Giri, B.; Xue, M.; Zhao, J.; Chen, S.; Shen, H.; Shen, G.; Wang, R.; Cao, J.; et al. Spatial distribution and seasonal variation of atmospheric bulk deposition of polycyclic aromatic hydrocarbons in Beijing Tianjin region, North China. Environ. Pollut. 2011, 159, 287-293. [CrossRef] [PubMed]

30. Gladtke, D.; Bakker, F.; Biaudet, H.; Brennfleck, A.; Coleman, P.; Creutznacher, H.; Van Egmond, B.F.; Hafkenscheid, T.; Hahne, F.; Houtzager, M.M.; et al. Different collector types for sampling deposition of polycyclic aromatic hydrocarbons-Comparison of measurement results and their uncertainty. J. Environ. Monit. 2012, 14, 2054-2062. [CrossRef]

31. Liu, F.; Xu, Y.; Liu, J.; Liu, D.; Li, J.; Zhang, G.; Li, X.; Zou, S.; Lai, S. Atmospheric deposition of polycyclic aromatic hydrocarbons (PAHs) to a coastal site of Hong Kong, South China. Atmos. Environ. 2013, 69, 265-272. [CrossRef]

32. Settimo, G.; Viviano, G. Atmospheric depositions of persistent pollutants: Methodological aspects and values from case studies. Ann. Ist. Super. Sanità 2015, 51, 298-304. [PubMed]

33. Fiedler, H.; Buckley-Golder, D.; Coleman, P.; King, K.; Petersen, A. Compilation of EU dioxin exposure and health data: Environmental levels. Organohalogen Compd. 1999, 43, 141-144.

34. Lee, K.-L.; Lee, W.-J.; Mwangi, J.K.; Wang, L.-C.; Gao, X.; Chang-Chien, G.-P. Atmospheric PM2.5 and depositions of polychlorinated Dibenzo-p-dioxins and dibenzofurans in Kaohsiung area, Southern Taiwan. Aerosol Air Qual. Res. 2016, 16, 1775-1791. [CrossRef] 
35. Ngo, T.H.; Tsou, H.H.; Chen, Y.F.; Chen, Y.W.; Chi, K.H. Sources identification of PCDD/Fs in soil and atmospheric deposition in Taiwan. Chemosphere 2018, 208, 374-381. [CrossRef] [PubMed]

36. Avino, P.; Russo, M.V. A comprehensive review of analytical methods for determining persistent organic pollutants in air, soil, water and waste. Curr. Org. Chem. 2018, 22, 939-953. [CrossRef]

37. Deng, Y.; Peng, P.; Jia, L.; Yin, H.; Hu, J.; Mao, W. Atmospheric bulk deposition of polychlorinated dibenzo-p-dioxins and dibenzofurans (PCDD/Fs) in the vicinity of MSWI in Shanghai, China. Ecotoxicol. Environ. Saf. 2020, 196, 110493. [CrossRef]

38. Nevalainen, L.; Tuomisto, J.; Haapasaari, P.; Lehikoinen, A. Spatial aspects of the dioxin risk formation in the Baltic Sea: A systematic review. Sci. Total Environ. 2021, 753, 142185. [CrossRef]

39. Fang, M.; Choi, S.-D.; Baek, S.-Y.; Jin, G.; Chang, Y.-S. Deposition of polychlorinated biphenyls and polybrominated diphenyl ethers in the vicinity of a steel manufacturing plant. Atmos. Environ. 2012, 49, 206-211. [CrossRef]

40. Mangia, C.; Cervino, M. Modelling wet and dry depositions of PCDD/F releases from industrial plants in Apulia, Southern Italy. Int. J. Environ. Pollut. 2012, 48, 185-193. [CrossRef]

41. Brambilla, G.; De Filippis, S.P.; Esposito, V.; Settimo, G. Dioxin like compounds bulk deposition on corn (Zea mais) and alfa alfa (Medicago sativa): Modelled levels on derived silage and hay and their relevance for dairy production. Clean Soil Air Water 2013, 41, 113-118. [CrossRef]

42. Onofrio, M.; Spataro, R.; Botta, S. Deposition fluxes of PCDD/Fs in the area surrounding a steel plant in northwest Italy. Environ. Monit. Assess. 2014, 186, 3917-3929. [CrossRef]

43. Rada, E.C.; Ragazzi, M.; Schiavon, M. Assessment of the local role of a steel making plant by POPs deposition measurements. Chemosphere 2014, 110, 53-61. [CrossRef]

44. Chuang, K.-Y.; Lai, C.-H.; Peng, Y.-P.; Yen, T.-Y. Characteristics of particle-bound polychlorinated dibenzo-p-dioxins and dibenzofurans (PCDD/Fs) in atmosphere used in carbon black feeding process at a tire manufacturing plant. Environ. Sci. Pollut. Res. 2015, 22, 19451-19460. [CrossRef]

45. Van Dijk, C.; van Doorn, W.; van Alfen, B. Long term plant biomonitoring in the vicinity of waste incinerators in The Netherlands. Chemosphere 2015, 122, 45-51. [CrossRef] [PubMed]

46. European Community. Communication from the Commission to the Council, the European Parliament and the Economic and Social Committee Community—Strategy for Dioxins, Furans and Polychlorinated Biphenyls /* COM/2001/0593 final */. Off. J. Eur. Union 2001, 322, 2-18.

47. European Community. Communication from the Commission to the Council, the European Parliament and the Economic and Social Committee. On Implementation of the Community Strategy for Dioxins, Furans and Polychlorinated Biphenyls (COM(2001) 593). Brussels, 13/4/2004. COM(2004) 240 Final. Available online: https://eur-lex.europa.eu/legal-content/EN/ TXT/PDF/?uri=CELEX:52004DC0240\&from=EN (accessed on 18 February 2021).

48. European Community. Council Decision of 14 October 2004 Concerning the Conclusion, on Behalf of the European Community, of the Stockholm Convention on Persistent Organic Pollutants. Off. J. Eur. Union 2006, L209, 1-2.

49. European Community. Communication from the Commission to the Council, the European Parliament and the Economic and Social Committee. On Implementation of the Community Strategy for Dioxins, Furans and Polychlorinated Biphenyls (COM(2001) 593)—Second Progress Report. Brussels, 10/7/2007. COM(2007) 396 Final. Available online: https: / / eur-lex.europa. eu/legal-content/EN/TXT/?uri=CELEX\%3A52007DC0396 (accessed on 18 February 2021).

50. Decreto Legislativo 13 agosto 2010, n.155. Attuazione della direttiva 2008/50/CE relativa alla qualità dell'aria ambiente e per un'aria più pulita in Europa. Gazz. Uff. 2010, 216 (Suppl. 217). Available online: https://www.camera.it/parlam/leggi/deleghe/ testi/10155dl.htm (accessed on 18 February 2021).

51. UNI EN 15980:2011. Air Quality_Determination of the Deposition of Benz[a]anthracene, Benzo[b]fluoranthene, Benzo[j]fluoranthene, Benzo[k]fluoranthene, Benzo[a]pyrene, Dibenz[a,h]anthracene and Indeno[1,2,3-cd]pyrene; UNI: Milan, Italy, 2011.

52. UNI EN 15841:2009. Ambient Air Quality—Standard Method for Determination of Arsenic, Cadmium, Lead and Nickel in Atmospheric Deposition; UNI: Milan, Italy, 2010.

53. UNI EN 1948-2:2006. Stationary Source Emissions-Determination of the Mass Concentration of PCDDs/PCDFs and Dioxin-Like PCBs_-Part 2: Extraction and Clean-Up of PCDDs/PCDFs; UNI: Milan, Italy, 2006.

54. UNI EN 1948-3:2006. Stationary Source Emissions-Determination of the Mass Concentration of PCDDs/PCDFs and Dioxin-Like PCBs_Part 3: Identification and Quantification of PCDDs/PCDFs; UNI: Milan, Italy, 2006.

55. UNI EN 1948-4:2010+A1:2013. Stationary Source Emissions—Determination of the Mass Concentration of PCDDs/PCDFs and Dioxin-Like PCBs_Part 4: Sampling and Analysis of Dioxin-Like PCBs; UNI: Milan, Italy, 2006.

56. Agenzia Regionale per la Prevenzione e la Protezione dell'Ambiente Valle d'Aosta (ARPAVDA). Risultati della Campagna di Monitoraggio delle Deposizioni Atmosferiche Totali Condotta nel Periodo Giugno 2006-Luglio 2007; ARPA VDA, Air Laboratory: Saint-Christophe, Italy, 2008. Available online: https://www.arpa.vda.it/images/stories/ARPA/aria/datiQA/deposimetri/ relazione_deposimetri_2006_2007.pdf (accessed on 10 January 2021).

57. Turrio-Baldassarri, L.; Battistelli, C.A.; di Domenico, A.; Iamiceli, A.L.; Iacovella, N.; Mazzoli, P.; Settimo, G.; Viviano, G. A study on PCDD and PCDF contamination in a case of public concern. Organohalogen Compd. 2002, 59, 181-184.

58. Agenzia Regionale per la Prevenzione e la Protezione dell'Ambiente Umbria (ARPA Umbria). Ricerca Diossine e PCB. Attività svolta da Arpa nel Periodo 2003-2010. Available online: http:/ / www.arpa.umbria.it/resources/documenti/aria/RICERCA\%20 DIOSSINE.pdf (accessed on 8 January 2021). 
59. Agenzia Regionale per la Prevenzione e la Protezione dell'Ambiente Puglia (ARPA Puglia). Il Monitoraggio della Qualità dell'Aria Taranto; Aggiornamento all'Anno 2019 (2008-2019); ARPA Puglia, Dap Taranto Servizi Territoriali Polo Microinquinanti Organici: Taranto, Italy, 2019. Available online: http:/ / www.arpa.puglia.it/c/document_library/get_file?uuid=5e6a8e07-73ce-41d5-84c3 -f6400a5bdea6\&groupId $=13883$ (accessed on 8 January 2021).

60. Bove, B.; Cattani, G.; Cusano, M.C.; De Luca, S.; Dellatte, E.; di Domenico, A.; Fochi, I.; Fulgenzi, A.R.; Iacovella, N.; Inglessis, M.; et al. PCDD, PCDF, and PCB baseline levels in air near a waste incineration plant site in southern Italy. Organohalogen Compd. 2005, 67, 2083-2085.

61. Desmedt, M.; Roekens, E. New policy in Flanders to link environmental levels of PCDD/F and dioxin-like PCBs to health. Organohalogen Compd. 2011, 73, 2042-2045.

62. Landesanstalt für Umweltschutz Baden-Württemberg. Literaturstudie zur Ermittlung des Depositionswertes von Dioxinen, Furanen und Dioxinähnlichen PCB; Landesanstalt für Umweltschutz Baden-Württemberg: Karlsruhe, Germany, 2004; Available online: http:/ / www4.lubw.baden-wuerttemberg.de/servlet/is/14558/ (accessed on 27 December 2020).

63. Kirchner, M.; Freie, K.P.; Denner, M.; Ratz, G.; Jakobi, G.; Korner, W.; Ludewig, E.; Schaub, M.; Schramm, K.-W.; Weiss, P.; et al. Air concentrations and deposition of chlorinated dioxins and furans (PCDD/F) at three high alpine monitoring stations: Trends and dependence on air masses. Atmos. Environ. 2020, 223, 117199. [CrossRef]

64. Vikelsoe, J.; Hovmand, M.; Andersen, H.V. PCDD/F in deposition, spruce throughfall and air in Denmark. Organohalogen Compd. 2003, 61, 454-457.

65. Oxbol, A.; Schleicher, O.; Fuglsang, K.; Jensen, A.A.; Borg-Jensen, K.; Schilling, B. Dioxin deposition around a danish municipal incinerator. Organohalogen Compd. 2002, 57, 369-372.

66. Air Rhône-Alpes. Programme de Suirvaillance des Dioxines, Furanes, \& Metaux Lourds. 2015. Available online: https://www. atmo-auvergnerhonealpes.fr/sites/ra/files/atoms/files/surveillance_dioxines_metaux_lourds-synthese_2013-2014.pdf (accessed on 10 January 2021).

67. Soggiu, M.E.; Inglessis, M.; Gagliardi, R.V.; Settimo, G.; Marsili, G.; Notardonato, I.; Avino, P. PM 10 and PM 2.5 qualitative source apportionment using selective wind direction sampling in a port-industrial area in Civitavecchia, Italy. Atmosphere 2020, 11, 94. [CrossRef]

68. Alam, M.S.; Keyte, I.J.; Yin, J.; Stark, C.; Jones, A.M.; Harrison, R.M. Diurnal variability of polycyclic aromatic compound (PAC) concentrations: Relationship with meteorological conditions and inferred sources. Atmos. Environ. 2015, 122, 427-438. [CrossRef]

69. IARC. Overall Evaluations of Carcinogenicity: An Updating of IARC Monographs Volumes 1 to 42; IARC Monographs on the Evaluation of Carcinogenic Risks to Humans, Supplement 7; International Agency for Research on Cancer: Lyon, France, 1987.

70. WHO. Air Quality Guidelines for Europe, European Series No. 91, 2nd ed.; World Health Organization, Regional Office for Europe: Copenhagen, Denmark, 2000.

71. Manoli, E.; Samara, C.; Kostantinou, I.; Albanis, T. Polycyclic aromatic hydrocarbons in the bulk precipitation and surface waters of Northern Greece. Chemosphere 2000, 41, 1845-1855. [CrossRef]

72. Arellano, L.; Fernández, P.; van Drooge, L.B.; Rose, N.L.; Nickus, U.; Thies, H.; Stuchlík, E.; Camarero, L.; Catalan, J.; Grimalt, J.O. Drivers of atmospheric deposition of polycyclic aromatic hydrocarbons at European high-altitude sites. Atmos. Chem. Phys. 2018, 18, 16081-16097. [CrossRef]

73. Agenzia Regionale per la Prevenzione e la Protezione dell'Ambiente Valle d'Aosta (ARPAVDA). Monitoraggio delle Deposizioni Atmosferiche-Periodo 2010; ARPA VDA, Air Laboratory: Saint-Christophe, Italy, 2010. Available online: https:/ /www.arpa.vda. it/images/stories/ARPA/aria/datiQA/deposimetri/relazione_deposimetri_2010.pdf (accessed on 10 January 2021).

74. Agenzia Regionale per la Prevenzione e la Protezione dell'Ambiente Umbria (ARPA Umbria). Qualità dell'Aria in Umbria: Valutazioni e Analisi di Microinquinanti; ARPA Umbria: Terni, Italy, 2015. Available online: https://www.arpa.umbria.it/MC-API/ Risorse/StreamRisorsa.aspx?guid=6497cd9c-7cfa-4e82-85cf-e30d0c6fbfec (accessed on 8 January 2021).

75. OSPAR Commission. Pilot Study and Intercomparison Exercise on Atmospheric Inputs of PAHs. Available online: https: / / www.ospar.org/documents? v=6925 (accessed on 18 February 2021).

76. European Communities. Ambient Air Pollution by As, Cd and Ni Compounds; Position Paper. Prepared by the Working Group on As, Cd and Ni compounds; Office for Official Publications of the European Communities: Luxembourg, 2001. Available online: http:/ / europa.eu.int/comm/environment/air/pdf/pp_as_cd_ni.pdf (accessed on 12 October 2020).

77. Avino, P.; Capannesi, G.; Rosada, A. Ultra-trace nutritional and toxicological elements in Rome and Florence drinking waters determined by Instrumental Neutron Activation Analysis. Microchem. J. 2011, 97, 144-153. [CrossRef]

78. Avino, P.; Capannesi, G.; Renzi, L.; Rosada, A. Instrumental neutron activation analysis and statistical approach for determining baseline values of essential and toxic elements in hairs of high school students. Ecotoxicol. Environ. Saf. 2013, 92, 206-214. [CrossRef] [PubMed]

79. Settimo, G.; Soggiu, M.E.; Inglessis, M.; Manigrasso, M.; Avino, P. Submicron and ultrafine particles in downtown Rome: How the different euro engines have influenced their behavior for two decades. Atmosphere 2020, 11, 894. [CrossRef] 